\title{
Integrated Development of Tourism Villages In Mt. Merapi Area, Sleman, Daerah Istimewa Yogyakarta
}

\author{
Team: \\ Yeremia Jonathan Jemadu, Anisa Haqqi, Ferdiansyah Maydelta, Sella Sades, Maliki Dwi Ibrahim, \\ Shita Oktaviani, Yasmin Syadza Firstiarin, Siti Komala Dasanti, Nur Setia Fatmawati \\ Advisor : \\ Bpk. Hery Sigit Cahyadi, Bpk. Haryadi Darmawan, Bpk. Rachmat Syam \\ Tourism Programme - Study of Tourism Destination \\ Bandung Institute of Tourism \\ Dr. Setiabudhi Street 186, Bandung 40141 - Telp +62 22011456
}

\begin{abstract}
Mt. Merapi area is one of the main tourism destination in Yogyakarta Province which has several tourism villages, such as Pentingsari, Pulesari, Petung, Kinahrejo, Kelor, Gabugan, Garongan, Trumpon, and Tunggul Arum. But, all of these tourism villages still runs itself so they compete each other and made gap of number visitor between tourism villages. In other way that condition made some tourism villages not active, even though has a potential attraction. Based on UU No.16/2014, village should be built a team work with another village. In this research using integration as the grand theory according to the book Vacationscape, Gunn (1998), there are three aspects stakeholders, supporting factor and tourism management. In order to integrate the area using integration tools which are cluster system, visitor management technique and destination management organization, Morrison (2013) that can help visitor to enhance the experience in visiting tourism village. The method of this research is descriptive qualitative method. Types of data in this research are primary and secondary data. Primary data we got from interview with every key persons from the tourism villages. Secondary data we got from Department of Culture and Tourism Sleman Regency. This research using descriptive data analysis technique with the steps of data collection, data reduction and display the data presented in narrative text. The result this research show that internal stakeholder (tourism villages pioneer) as key person has a mayor influence in influencing tourism village development. The supporting factors of tourism, in Eastern Mount Merapi Desa Wisata Pentingsari can be used as a distribution center as well as Desa Wisata Pulesari in the western with use clustering system. The managers agreed with establishment organization or formal forum to become main tourism village in Sleman Regency, it expected can optimize the purpose which is organize tourism agenda.

Keyword - Yogyakarta; Tourism Village; Management (KeyWord)
\end{abstract}

\section{A. Background}

\section{INTRODUCTION}

Mt. Merapi area has 8 tourism village which can divided into three classifications: growing, developing, self-sufficient. Tourism village in 'growing' category are Tunggularum and Kinahrejo, tourism village in 'developing' category are Petung and Turgo, Tourism village in 'self-sufficient' category are Pentingsari,
Trumpon, Kelor, and Pulesari. The very strong village atmosphere makes this Mt. Merapi area became the center of the development of tourism villages that offer a wide range of appeal and tourist activity, but during the development of tourism villages is still not integrated and running individually. Every tourism villages still did not support each other, especially in the management and marketing of tourism products. In order to optimize the management of tourism villages there are now Tourism Village Communication Forum whose intended as a communication fabric between a tourism village at the same time to create a positive competition among tourism village. The role of Tourism Village Communication Forum nowdays essentially as a forum for exchanging information from every tourism village, but the discussion about market share was still rare so that these Tourism Village Communication Forum are often considered less effective. With the increasing levels of competition tourism villages in Mt. Merapi area need their ideas to integrate the development of rural tourism on Mt. Merapi area in order to provide a healthy climate of competition rating and distribute evenly to the tourism villages. Article 91 and Article 92 of Law No. 16 of 2014 on the village said that the village should be entered into a collaboration with other villages. The article also mentions the cooperation made through consensus agreement between the village and conducted by an inter-village cooperation through joint regulation village head.

Clare A. Gunn in his book entitled "Vacationscape" says that there are three dimensions in a region that integrates stakeholders, enabling factors of tourism and tourism manage ability. 1) Stakeholders, there are three main pillars of stakeholders who play a role in the development of the region, namely the government, private sector, and communities. The third group of stakeholders have each roles and functions and expected to build cooperation or 
partnership, either individually or in groups in its management. In realizing the partnership, researchers used the basic principles that exist on Destination Management Organization (Mill Morison, 2013) which also includes eight elements include Tourism Agenda, Coordination of Stakeholders, Passion for Tourism, Training and Development of Tourism, Tourism Marketing, Services visitor information, Tourism Quality Standards and Management of Resources. 2) The factors supporting tourism, according to Gunn (1998) in his book "Vacationscape" there are five factors supporting the tourism there are tourists, transport, attractions, facilities, and information. 3) tourism manageability, implicitly written by Gunn (1998) in his book "Vacationscape" tourism manageability include the board (management). So expect the later development of tourism villages in Mt. Merapi area can be integrated and create a positive competition between tourism village. Forms of such integration will be recommended to the Tourism Village Communication Forum, so it will become a new force in the development of Mt. Merapi area as one of the tourist destinations of Yogyakarta.

\section{B. Problem Formulation}

In this study, the researcher outlines the research problem formulation into this three question, there are:

1. Who are the key stakeholders whose involved in the development of tourism villages in Mt. Merapi area?

2. What are and how these factors supporting tourism (tourist, transportation, attractions, facilities, and information) on tourism villages in Mt. Merapi are can be integrated?

3. How does the management of tourism villages in Mt. Merapi area can be integrated?

\section{Objective}

The purpose of this research is to create a tourism village management with each key person integrate in the development of rural tourism through their formal organization.

\section{METHOD}

\section{A. Desain}

The research method that researchers use in this research is descriptive qualitative research methods. With this method researcher will make a systematic description or picture of how the role, enabling factors of tourism, and management of Rural Tourism in Mt. Merapi area based on the facts. Researchers chose to use a qualitative descriptive method because this study focuses on a complete picture of the phenomenon, events, social activities, attitudes beliefs, perceptions, thoughts individually or group of people who are in the tourism village of Mt. Merapi area.

\section{B. Population and Sample}

The population in this study is 9 (nine) tourism villages in Mt. Merapi area, Sleman, Yogyakarta. The villages include Pentingsari, Petung, Kinahrejo, Pulesari, Kelor, Gabugan, Garongan, Trumpon, and Tunggularum. Those villages are tourism villages that still officially recorded by Department of Culture and Tourism Sleman Regency and still active in developing village tourism.

Sampling technique that used in this research is purposive sampling technique, where a purposive sampling technique is sampling based on considerations of researchers adapted to the needs of research. Researchers decided to start looking through the data sources that are considered able to account statements and are considered more knowledgeable about the actual condition. So the researchers pointed to several people from each group of stakeholders, such as chairman, but if not then will proceed to the post below, or researcher chose randomly. In this study, nine stakeholders tourism villages in Mt. Merapi area comes from an agency and organizational structure, so the sampling will be imposed on the owners of top notch (chairman). However, if the condition does not allow researchers to conduct interviews, then the sampling will be dropped at the position right under the chairman and so on, but limited to level 4 in the organizational structure of the institution.

\section{Data Collects Techniques \\ - Interview}

Researchers will use the type of semi - structure interview, this type still require a list of questions but researchers still can add or subtract a question in accordance with the state of the respondent. Interviews conducted by researchers include: The government of Sleman likes Department of Tourism and Department of Regional Development, private parties such as owners of travel agents, people who are involved in tourism activities in the tourism village of Mt. Merapi area, business in tourism village, chief manager of the tourism village, the deputy chairman of the manager of a tourism village, or other officials tourism village located in the Mt. Merapi area. 


\section{- Observasi}

In this study, researchers will observe the supporting factors of tourism, located in a tourism village in Mt. Merapi area include: Transportation: The condition of roads, means of transport such as public transport, bus, taxi to facilitate the public or tourists to activity displacement between the village and outside the village which is in Mt. Merapi area. Attractions: The attraction and activities contained in the tourism village of Mt. Merapi area such as museum Ullen Sentalu, Volcano Tour Cangkringan, etc. Facilities: Support to facilitate tourism activities such as hospital, hotel, restaurant and café. Information: Make it easy for travelers to find out how to achieve and what activities are available in the tourism village in Mt. Merapi area and information relating to travel, while for stakeholders, information can make it easier for stakeholders to determine the development and oversee the things that happened in the tourism village in Mt. Merapi area, this information includes maps, brochures, articles in magazines, manuals, and on the internet. The tools used by researcher to get the data from this observation is that checklist.

\section{III.FINDING AND DISCUSSION}

Key person of internal stakeholders that have a major influence on the development of rural tourism in terms of power and interest are each pioneer in tourism village. This is due to the pioneer of tourism village provide feedback often heard and reconsideration by the managers of the tourism village. Besides the pioneers are the people who build a tourism village from scratch, on the other hand the pioneer also an elder people in each village tourism. The pioneers are the ones that will most influence in the process of integrating the tourism villages in Mt. Merapi area and therefore expected that the pioneer agreed and supported by all the ability in terms of integrating this tourism villages.

In addition to pioneering the most influence of internal stakeholders in terms of power and intersets, Department of Culture and Tourism Sleman also had the highest impact in terms of interest, just still not quite large in terms of the power of the external stakeholders. This is reinforced because Department of Culture and Tourism Sleman has an obligation to handle tourism village indicated by the establishment of a communication forum between the tourism village in Sleman. Department of Culture and Tourism Sleman expected to not only provide space for communication and freedom in the run, but is equipped with related regulations are established to maintain balance and integration between tourism village in it.

Factors supporting in the eastern and western of Mt. Merapi area: East there Pentingsari Tourism Village is a tourism village that is still active and gets a lot of tourists visit the post-eruption of Merapi. It makes Pentingsari Tourism Village as a tourist distribution center to be directed to the tourist attractions that are found in the eastern of Mt. Merapi area. From the pattern of distribution, is expected to revive the tourism village that vacuum after the eruption of Mt. Merapi in order to get involved again in tourist activity in the area of the eastern of Mt. Merapi area.

In the area of the western of Mt. Merapi area are six villages that are still active, but still more unequal number of tourist visits. Of the six active tourism village located in the western region, Pulesari Tourism Village is a tourism village that has the most number of visits. Many things that cause other tourism villages in the western region get tourists visit less than Pulesari Tourism Village. Through the cluster system, a tourism village can be grouped based on the characteristic of each village that is expected to reduce inequality in the number of visits by distributing the tourists not to visit any of the tourism village, and established a tourism village as a tourist distribution center. This makes the tourists can choose the program or tour packages according to the wishes and interests, as a tourism village on the slopes of Mount Merapi western part has a different characteristic between a tourism village. Besides expected to reduce inequality in the number of tourists and not only focused visit to the tourism village alone, the integration of tourism villages is also expected to revive the tourism villages that have been destroyed by the eruption, and can increase the number of tourists visit every tourism village.

In terms of manageability tourism village, the village manager of travel agency was agree to the establishment of a formal forum to be holding the entire tourism village in Sleman, especially in the slopes of Mount Merapi. Their communication forums that have been running up to now is still not optimal in the shade the whole purpose of a tourism village. So with a forum that is more formal is expected to optimize the entire purpose of a tourism village like organizing the tourism agenda, in collaboration with stakeholders, strengthen positive addition to the economy from tourism, provide tourism training, organize promotion of rural tourism, arrange the visit 
in terms of information, improving quality standards in every village, organize and maintain resource utilization.

In the tourism agenda can be concluded that in the short term that can be immediately implemented as giving conscious understanding of tourism to the community, repairing and renewing attractions, and improve system manageability tourism village. For long-term agenda is to develop and increase the rides at any tourist attraction. There stakeholders influential in the development of rural tourism which will be integrated on the slopes of Mount Merapi is the manager of the tourism village, the Department of Culture and Tourism Sleman, pioneering tourism village, and the villagers themselves. Another positive economic impact other than that felt by the public in the presence of rural tourism is increasing public hygiene and the environment, otherwise it becomes easier for people to interact and socialize with tourists, as well as awareness of the importance of tourism has increased. Training to improve knowledge and skills of managers and masyakrakat village on tourism was needed as tour guide training, cooking and crafts. In terms of marketing, tourism village in the Mt. Merapi area to promote itself as a tourism village-based nature, it will be arranged to create a campaign that is evenly distributed to each village, and prevent unfair competition between tourism village in this forum. Information services such as maps, brochures, manuals and websites need to be governed by this forum in order to help tourists get information about tourism village is complete and plenty of choice.

Each village homestay tours have almost met the standards set by the manager as cleanliness and safety. The quality of tour guides were already quite good but still has limitations in foreign languages. Access to the tourism village has been good so even with access inside the tourism village, but the size of the road is still narrow so often large vehicles such as buses parked on the roadside and outside the tourism village. It is note for the forum to find a way out an issues like this. In the use of its resources, the manager of a tourism village in the Mt. Merapi area work with the community to use resources wisely and use according to their needs.

\section{CONCLUSION AND SUGGESTION A. Conclusion}

According to the explanation above, the general conclusion of this study is to realize the integration of villages that must be considered by the key person of stakeholders that includes pioneer of tourism village and the Department of Culture and Tourism Sleman. Then the supporting factors of tourism which includes tourists, trasnportasi, attractions, facilities, and information that is formed in a pattern distribution service as well as the establishment of a more formal forum that will overshadow and manage all tourism village in Sleman.

\section{B. Suggestion}

Based on the above conclusions as for the advice that can be given to creating an integrated tourism village on the Mt. Merapi area is the establishment of the forum by the Department of Culture and Tourism Sleman that are more formal and shade throughout the villages that are members in terms of tourism agenda to be executed, coordination of the policy makers, the positive impact will be accepted, tourism development, marketing, information services, quality standards and the use of resources. Besides this forum to be set up should have the relevant regulations regarding tourism villages that are members in the forum in order to keep fellow members. In the establishment of the forum, the Department of Culture and Tourism Sleman also expected to include or pay attention also pioneers who became the key person each tourism village, in order to really create a forum that following by the tourism villages which are the members of the forum. But still must consider the factors supporting the tourism that will form a distribution pattern of rating that can be used as a trigger to revive the tourism villages that have died. With the distribution patterns can help one purpose of the establishment of the forum, which is leveling the number of tourist arrivals in tourism villages, so as not to gaps the number of tourists who come and help so that all tourism village in Mt. Merapi area can grow and the more forward together.

\section{REFERENCES}

[1] Gunn, C. A. (1998). Vacationscape : Designing Tourist Region. Austin: Bureau of Business Research The University of Texas.

[2] Morrison, A. M. (2013). Marketing and Managing Tourism Destinations. $\quad$ London: Routledge. 